One keeps hearing that: "We don't need to manage hardwoods for regeneration, because they regenerate themselves". But, why wait for natural regeneration of hardwoods at the risk of the sites being invaded by raspberries, red maple, aspen and other "weeds'? Why lose years of growth with slower growing hardwoods, when you could plant fast-growing hybrids, after mechanically preparing the sites.

Compare the problems and costs mentioned for natural regeneration and thinning, to the costs and opportunities which artificial regeneration gives you:

Mechanical site preparation will cost between $\$ 20$ and $\$ 70$ an acre on your better sites.

Add to this the cost of seeding or planting, and you have a total cost of $\$ 80$ to $\$ 160$ an acre, or a saving of at least $\$ 15$ over spacing.

Besides the cost advantage over spacing, you are able to establish the right species, with superior trees. The result: No loss of lead time, faster growth, and a shorter rotation.

And a shorter rotation is the best way to justify expenditures in silviculture.

Michael Sauze

\section{LOST MEMBERS}

Last known address as shown. Can you help?

H. E. Alexander, Box 2, Nackawic, N.B. EOH 1 PO

P. C. Anderson, 9916-77 St., Edmonton, Alta. T6A 3B7

D. N. Bacala, 429 Allard, Winnipeg, Man. R3K 1T1

J. P. Bielech, 11708 University Ave., Edmonton, Alta. T5G $1 Z 5$.

V. E. Bradford, Box 895, Ignace, Ont. POT ITO

Judy A. Briand, 25 Parkland Place, Unit 25, New Sudbury, Sudbury, Ont.

B. E. Burghardt No. 2-12918-118 Ave., Edmonton, Alta. T5L $2 L 4$.

Chung-Yeung Chong, Box 31, R.R. No. 2, Rabbit Lake Trailer Park, Kenora, Ont. P9N 3W8.

Christine Birkett, 76 1/2 York St., \#5, Fredericton, N.B. E3B 3N5.

H. A. Erickson, General Delivery, Macdowall, Sask. SOK 2SO.

R. W. Evered, Apt. No. 118-100 Seagram Dr., Waterloo, Ont. N2L. 3B8

L. D. Flaig, 9501-100th St., Grande Prairie, Alta. T8V 1B1.

R. Greet, 176 Windermere St., Thunder Bay, Ont. P7B 3R4.

H. P. Jensen, Box 152, Gold River, B.C. VOP $1 \mathrm{GO}$.

J. D. Kelly, 48-445 SW Marine Dr., Vancouver, B.C. V5X 2 R9.

A. D. J. Ker, No. 502-1686 W 12th Ave., Vancouver, B.C. V6J $2 \mathrm{E} 4$.

Susan Ker, 858 Brunswick St., Fredericton, N.B. E3B 1J1.

T. K. Killins, 102 Seagram Drive, Apt. 203, Waterloo, Ont. N2L 3B8.

J. A. Osborne, 107 Colborne St., Apt. 505, Lindsay, Ont. K9V 3 T4.

Crystal S. Patch, 278 Northumberland St., Fredericton, N.B. E3B $3 J 7$.

R. G. Ray, 346 Bronson Ave., Ottawa, Ont. K1R 6J3.

M. A. Rokak, 107 Colborn St., Apt. 506, Lindsay, Ont. K9V 3T4.

C. R. Rogers, 5 Devonshire Place, Toronto, Ont. M5S 2C3.

E. A. Sauder, $101-2174$ York St., Vancouver, B.C. V6K $1 \mathrm{C} 3$.

A. C. Treadaway, Apt. 7E, Park W., 2366 Portage Ave., Winnipeg, Man. R3J OM8.

B. Voldock, Box 548, Barry's Bay, Ont. K0J 1 B0.

W. J. Zammit, $206-10620-79$ th St., Edmonton, Alta. T6E 1 S1.

\section{Forest Memo No. 9 Money Does Grow on Trees!}

A few weeks ago, the Association of British Columbia Professional Foresters protested, in a brief to Cabinet, the sale of forest land for other uses without anyone doing a cost/benefit analysis. Fourteen BC organizations endorsed the brief. These included not only the forest industry associations and the three forest unions but also the Federation of Naturalists, the Wildlife Federation, the Federation of Agriculture and the Cattlemen's Association. It is an important issue that unites such diverse interests.

The brief highlighted the value of the forest and the serious effects everyone would suffer if the land base for this resource were further whittled away. One of the important points it made was the folly of selling land with young trees at upset prices far below the value of these trees. This memo deals with that problem.

Probably everyone has seen these lands. A lot of people might call them brush, not noticing the new crop of young trees coming up after earlier logging or fires. Because these young trees ("immature" to the forester) are not big enough to be useful today, it is easy to make the mistake of thinking they aren't worth anything. Even the Ministry of Forests uses very conservative values when calculating damage to them from fire or other causes. For example, let us take a twenty-five year old fir forest in the Interior of B.C. For damage calculations, it is valued at $\$ 225$ per acre, but let's look at its real value.

At today's lumber and pulp prices, the value of a cubic foot of wood converted to those products is about two dollars. That's the wealth it creates in taxes, profits, jobs and so on. At the growth rates we can expect in this fir forest, after twenty-five years, an acre has enough of those two dollar measures of wood to be worth anywhere from $\$ 700$ to $\$ 2,500$.

But, someone might say, the trees are too small to make pulp or lumber. Sure. But a forest doesn't suddenly become worth $\$ 10,000$ an acre on just the day it matures. Its value increases every single year and that twenty-five year old "brush"' is a third of the way along to maturity and, as the figures show, worth five or ten times what even the Ministry of Forests uses in estimating damage.

It takes a proper cost/benefit analysis to work out the value of such young forest compared to other uses. Meanwhile, not one acre should be sold without this commonsense step. Just because the trees don't look like much to the untrained eye, don't underestimate their worth.

Think of it in another context. Would a farmer turn cows into a half-grown wheatfield because the wheat didn't yet have any value as grain? Of course not. He would figure out the advantages and disadvantages before deciding to let the cattle loose or let the graın mature.

Can we afford to be any less prudent?

\section{Erratum}

Foliar Analysis and DRISS as a Guide to Fertiliser Amendments in Poplar Plantations, by R. H. Leech and Y. T. Kim. For. Chron. 57(1):17-21 on page 19. The first line of Table 4 should read:

$$
N \text { index }=[f(N / P)+f(N / K)+f(N / C a)+f(N / M g)] / 4
$$

there sould be no - sign in the first term. 